Teologia i Moralność, volumen 16(2021), numer 1(29)

doi: 10.14746/TIM.2021.29.1.9

ORCID: 0000-0002-1727-8012

ORCID: 0000-0002-1825-0345

\author{
PIOTR GUZDEK \\ University of Opole \\ Polish Family Association \\ REV. JAROSŁAW JĘCZEŃ \\ John Paul II Catholic University of Lublin
}

\title{
Clinical miscarriage from the perspective of multifaceted contexts of procreative loss
}

Clinical miscarriage is one of the pathologies of early pregnancy resulting in the death of a baby before it is able to live outside the womb. The formal criterion qualifying obstetric failure as a miscarriage of a clinically diagnosed pregnancy is the uncompleted 22nd week of prenatal development and the condition of foetal weight below 500g (Callahan, Caughey and Heffner 2004, 12). According to conservative estimates, $15-20 \%$ of fetuses fail to reach the due date because of clinical miscarriage (García-Enguídanosa, Calle, Valero, Luna and Domínguez-Rojas 2002, 111). One in four women in their obstetric history experience a loss of a child as a result of pregnancy complication, a miscarriage in its early stages (Panay, Dutta, Ryan and Broadbent 2006, 187).

Clinical miscarriage is not only a biomedical phenomenon, but determines a number of psychosocial contexts specific to this form of procreative loss and distinguishing this type of thanatic event from other circumstances of human death. The anthropological context determining the ontic and ethical status of the prematurely dying person and their corpse and remains as well as the social identity of the immediate circle of the bereaved family comes to the fore. The miscarrying process is inscribed in the context of the gradually developed prenatal bond in the nuclear family of the miscarried child; hence it obtains its unique relational aspect. The non-obviousness in the social awareness 
of the state of mourning and the need to work through the loss after miscarriage shapes a unique context of psychological repercussions for the parents experiencing miscarriage, demanding adequate accompaniment for the bereaved and the provision of corresponding social support initiated by the medical staff in the maternity ward.

It is only in the perspective of the four indicated contexts - anthropological, relational, psychological and supportive - that miscarriage appears as a non-obvious, distinct and multifactorally conditioned phenomenon of human death. Its adequate consideration requires an interdisciplinary research approach that goes beyond biomedical categories towards holistic psychosocial and axiological approaches.

This paper undertakes an analysis of the aforementioned contexts of clinical miscarriage in order to select the one which, to a decisive extent, entails its specificity as the death of a human individual. In order to achieve the research objective thus defined, the methods of analysis, synthesis and desk research were applied.

Given formal constraints, a more detailed characterization of the spiritual consequences of prenatal loss and pastoral accompaniment of orphaned parents is reserved for a separate study, and the authors also make a reference to their previous contributions on this topic (Guzdek 2017, 2019, 2020a, 2020b). Similarly, the discussion of the dynamics of prenatal bond development and the psychological implications of miscarriage is limited to the experience of the parental couple.

\section{Anthropological context of procreative loss}

The anthropology of clinical miscarriage clarifies the status of the human foetus and the corollary social identity of the parental system experiencing miscarriage. The criterion for valuing the human prenatal stage largely determines the symbolic meaning given to the procreative loss suffered and the kind of cultural scripts applied by the parents themselves and by their accompanying community in order to work through the experience. Defining miscarriage in the anthropological dimension as an event which fully meets all the characteristics of the death of a human being situates the couple experiencing miscarriage in the role of the bereaved parents confronted with a farewell to their deceased child and parental mourning. The opposing symbolic narrative identifies miscarriage only with the premature termination of pregnancy which, despite the fact that it objectively constitutes some form of failure in the realisation of procreative plans, requires, first and foremost, the necessary efforts be made to restore complete homeostasis allowing for the achievement 
of a full-term conception guaranteeing the physiological development of the new foetus and the birth of a healthy child. The first scenario therefore equates miscarriage with a thanatic crisis of a couple experiencing the death of a child in the early stages of its personal development. This interpretation creates an obligation of psychosocial support for parents who require a relatively long healing process after the death of their first child in order to be able to start trying to conceive another child. The personalisation of the child in the prenatal stage corresponds to the prenatal stage of parenthood of the parents experiencing miscarriage and to the formation of the identity of the actual rather than future parents in the social community. In the second scenario, miscarriage appears as an obstetric crisis to be overcome in the shortest possible time and to be entirely focused on the further realisation of the procreative project of the family without relating the cultural code inherent in the death of a person and the identification of the partners' parental identity to the non-personal foetus. The man and woman remain in the role of a couple with a previous failure in the obstetric history of their relationship now initiating immediate efforts for a live birth. Only the first live-born child, and not the previously miscarried one, makes the partnership a parental couple, even if the number of miscarried children in the family exceeds the number of live-born children.

Anglo-Saxon bioethics is dominated by an anthropological approach setting the assumptions of a depersonalised narrative of clinical miscarriage centred on the ethical principle of quality of life. The ethics of quality of life is a product of utilitarian thinking about the human person in the prenatal developmental age and borderline states (Galuszka 2006, 21-22). It is based on the premises of transcendental or materialistic ontology creating a specific type of descriptive personology ${ }^{1}$ radically separating and directly opposing the humanity of a human being with its personality (Hołub 2010, 97-98). Hence, it distinguishes non-personal humanity and personality that is not humanity (Ciach 2013, 108-111). In the ethics of quality of life, the category of person-

${ }^{1}$ In line with the typology of C.S. Bartnik, the founder of the Lublin personalistic school, by personology (also interchangeably called prosopology) one wants to understand each current of anthropology which has a personalistic orientation (anthropological personalism) and which constitutes an element of a bigger whole, i.e. a particular philosophical direction (Thomism, Marxism, phenomenology, etc.), which is not a personalistic system in itself. At the same time personology is also part of a philosophical or theological orientation that is a personalistic system (systemic personalism) as its anthropological component. Thus personalism in the sense of personology (a narrower concept) is distinguished from personalism in the sense of a system (a broader concept). In the personalistic system both personalistic ontology and personology, i.e. personalistic anthropology are developed, the former being the basis for the latter. In Marxism or phenomenology, on the other hand, personology is developed, not on the basis of a personalistic ontology, but on the basis of materialistic (within Marxism) or phenomenological (within phenomenology) ontology. In other words, Thomists, Marxists or phenomenologists can become personologists, yet, they are not representatives of systemic personalism (Cz.S. Bartnik 2006, p. 41n). 
ality does not have an ontic character, but is a psychological-functional construct radically distanced from the metaphysical structure of being, enabling it to transcend the boundary of species affiliation and to give personality a transspecies meaning in the circle of material entities with the exclusion of the context of transcendent personal entities proper for Christian theology: angelic and divine. Consequently, apart from human beings, the group of personal subjectivities may also include animal individuals at a higher level of neurological development (Hołub 2012, 107-122; Lohner 2002, 51-53). The fact of belonging to the human species and personal genesis, that is conception and birth from human parents, is no longer sufficient to establish the personal status of a given foetal individual. The foetus, in order to be recognised as a person, must fulfil descriptive criteria of personalisation which are available to a threshold extent also for animals revealing a higher level of psychism (Muszala 2012, 17-39).

Among the representatives of the ethics of quality of life, there is no consensus as to which personal qualities are sufficient for adjudication of personal status and what level of their manifestation is required for positive verification of the acquisition of personality by a particular individual (Holub 2016, 45-46). These include the ability to feel pain, self-awareness, symbolic communication, purposeful action, acts of self-determination and so forth. (Biesaga 2002, 55-58). The person becomes a kind of correlate of personal phenomena. The very subject of these features is deliberately omitted, focusing attention only on personal abilities manifested with varying intensity.

Following this, quality of life ethicists make a periodization of the life of a human being, specifying in it the pre-human and human, pre-personal, personal and post-personal stages (Szawarski 2005, 26). At least until the moment of implantation of the embryo in the uterine mucosa, the conceived child is treated as a preembryo that is an embryonic creation in the pre-human stage. The implantation, which is supposed to guarantee its individualisation (that is also the loss of the ability to divide into monozygotic twins), is considered to be the beginning of human life and the transition of the preembryo to the stage of the embryo proper. From this point of development onwards one can speak, according to descriptive personologists, of the beginning of human existence, but until other criteria of personalization are fulfilled, the human being remains a non-personal human being. Therefore embryos and foetuses have the status of 'a future person', 'a potential person', 'not yet a person'. When the human individual has acquired the required personal abilities, he passes into the stage of 'a fully-fledged person', 'an actual person' or 'a cognitively mature person'. For most quality of life ethicists, the human foetus never reaches this stage. They push the threshold of personalisation to the time of birth or even later in the developmental period, excluding from the group of persons 
also new-borns, infants and children up to the age when they develop abstract thinking and self-awareness of their subjectivity. A genetic syndrome or a developmental defect may disable the manifestation of personal traits; hence a child who carries them will never be recognised as a person (Murphy 1985, 79-83). Some descriptive personologists even question the human nature of the defective embryo and consequently its belonging to a species (George and Gómez-Lobo 2005, 201-210). As a result of various fortuitous events or the progressive process of ageing, 'the fully mature person' may suddenly or successively lose its personal status and pass into the post-personal stage.

Quality of life ethicists only attribute proportionate personal rights, including the right to life, to the individual at the stage of the 'actual person'. The notion of universally valid human rights established in popular thinking on the grounds of the quality of life ethics includes the principles of only selected individuals who meet the descriptive criteria of personalization, differentiating humanity understood strictly biologically from personality in the functionalpsychological sense. It is therefore possible to be an individual belonging to the human species, such as children in the embryonic and foetal stages, and yet not have a personal identity and consequently be deprived of the right to life and membership of a social community. One can also pre-exist as a fully cognitively mature person and enjoy the legal and ethical protection of life, and yet unexpectedly or gradually lose one's position as a person and one's inherent rights.

The functionalist-descriptivist project of personal subjectivity is not really a personalist vision of man, but is a specific manifestation of personalism. Personism as a reductionist anthropological direction opposed to ontological personalism recognizes only those foetal individuals as entitled to have a personal status and protection of the inviolability of their life who meet the descriptive criteria of personalization (Ciach 2013, 181). This stems from the fact of regarding the prenatal period of a human being as a run-of-the-mill stage of growth on the trail of a person's development (Kornas-Biela 2009, 122). The incompleteness of the pre-natal phase is demonstrated by comparing the degree of cognitive and psychosocial immaturity of the foetus with the developmental states achieved in the post-natal period. Personism evaluates foetal competence from the perspective of the postnatal developmental achievements of a new-born, a school child or a fully neurobiologically and psychologically mature person. Such an evaluation criterion, which is so incompatible with the tasks and developmental goals of the prenatal stage and which is in fact a measure of development occurring in the further postnatal stages, inevitably leads to the depreciation of foetuses and to the drawing of negative ontological, anthropological, ethical and legal conclusions on the basis of unfavourable empirical data for the nasciturus. In assessing the ontic status of the foetus, 
personalism poses empirical requirements that are objectively untenable in the prenatal phase. It denies the principle of the succession of developmental phases, the adequate evaluation of an individual's competence pursuant to the developmental state corresponding to the currently realised stage of growth, the integral treatment of each stage of development as a stage which is, on the one hand, autonomous in the tasks defining it and exclusively specific to it, and on the other hand, closely related to the preceding and subsequent stages. Personism, following selectively chosen empirical criteria, unjustifiably underestimates the value of the pre-natal stage, contrary to the dynamics of human development taking place there, which the post-natal stages do not equal. Its extraordinary intensity, the unprecedented range of changes and the scale of competence acquired by the foetus in less than nine months of foetal life have been empirically confirmed by embryology. At no stage of postnatal life does a human being develop with such a pace and such a wide range of changes as in the prenatal period (Kornas-Biela 2009, 122).

The criteria of personal status put forward within personism reveal its internal inconsistency, either taking the form of biological-developmental, cognitive-psychological factors or ethical-axiological ones, which leads to the confusion of different orders of being. In the case of biological criteria relating to the pre-implantation stage, the personality of the zygote is questioned due to totipotential abilities intended to undermine its individualisation (Melina $2016,112,115$ ). At this episode of ontogenesis, indivisible individuality is assumed as an exhaustive premise for the personalization of the embryo. T. Ślipko recognised the pre-implantation individualisation of the zygote as a stage of preparation for animation. Its empirical confirmation is to be provided by completed implantation (Ślipko 1994, 117-121). Simultaneously, just after passing the threshold of successful nidation, other descriptivists reject this achieved and previously strongly postulated individuality as a boundary condition of embryo personalization. Therefore N. Ford shifted the threshold of embryo individuation to the stage of post-implantation gastrulation (Ford 1995). Descriptivists who reduce a person to the level of phenomenal facticity raise, in turn, a demand for the implanted embryo to upgrade further descriptive features (Gorczyca 2014, 85). As is evident, only in this one issue of the individualization of the embryo can the supporters of successive personalization not reach an agreement.

The depersonalisation of the living foetus conducted on the grounds of personalistic anthropology results in an inevitable negation not only of the personalistic status of the ontic foetus, but also extends its implications to the ontic and ethical position of its miscarried corpse and remains. Extracted or naturally discharged from the uterine cavity, the dead foetus is reduced to the level of the dead tissue of the mother's body; hence it is not granted the status 
of a human corpse, but that of medical waste. It can also be identified as a miscarriage material which, albeit in terms of species corresponds to a corpse of a human individual different from the mother's body, is not a material residue of a personal body which participated in the ontic dignity of the deceased subject, but a dead substrate of a biological-human organism in the pre-personal stage (Morciniec 2000, 291). For descriptive personologists, the genetic criterion is not sufficient to consider the miscarried material as a human corpse, and therefore they may demand its verification in terms of meeting morphological criteria, especially the confirmation of a clearly formed humanoid structure of the fetus (Pilarz 2017, 61-62). Regardless of the decisions made in this regard, the corpse of a fetus miscarried before personalization is not entitled to the equivalent ethical protection resulting from the standard of reverence for the corpse of an individual who, before death, enjoyed the status of a cognitively mature person. Therefore a radical ontological difference emerges between the corpse of a non-personal foetus and a born human being who dies after personalization has been achieved. Consequently, a stillborn foetus is not subject to the obligation of burial, i.e. the return of its corpse to the earth in a form corresponding to the dignity of the personal subject (Morciniec 2009, 164-165). Thus, the corpse and fetal remains may be instrumentally utilized in the pharmaceutical or cosmetic industry or be disposed of, excluding the arrangement of a family burial (Morciniec 2013, 101n).

\section{Procreative loss in the context of the prenatal bond}

A different perspective on miscarriage is formulated by ontological-axiological personologists. In this variant of symbolic interpretation, procreative loss takes place at different stages of the formation of parental attachment to the prenatal child. The prenatal maternal and paternal relation satisfies three basic developmental tasks. These include recognition of the child's ontic separateness and its independence of existence, ascription of potential personal characteristics to the child that will gradually reveal themselves in the postnatal period as well as establishing and maintaining various forms of prenatal dialogue with it (Bielennik, Preis and Bidzan 2010, p. 223).

The course of development of the prenatal bond and the degree of its intensity are sexually differentiated (Bielennik, Preis and Bidzan 2010, 224). The key bonding events for both parents are the first ultrasound examination performed around the 12th week of pregnancy and the first sensations of the child's motor activity in the later weeks of the prenatal stage, whose availability to the father and mother is temporally and experientially incommensurable (Kornas-Biela 2009, 95-101). 
The formation of maternal attachment is a long-term process in which three basic stages may be distinguished. These include the stage of inclusion identical to the first trimester of pregnancy, the stage of differentiation coinciding with the second trimester and the stage of separation specifying the last, third trimester of pregnancy (Łuczak-Wawrzyniak 2012, 223-224; Lepiarz 2010, 54). Each stage is characterised by a distinctive way in which the woman perceives herself and her child and by a different level of intensity of the emotional bond (Łuczak-Wawrzyniak 2012, 223-224). The prenatal relationship between the mother and the child is characterised by its bio-affective specificity, because on the one hand it has a symbiotic dimension due to the multifaceted nature of bilateral interactions, while on the other hand it varies, due to the individualised nature of the relationship (Golen and Urbańczyk 2011, 96). The development of maternal attachment is multifactorially conditioned by, inter alia: the circumstances of conception, acceptance of the child by the father, the woman's obstetric history, the quality of the marital relationship, the stability of the family situation, emotional balance, the sense of self-worth, individual personality dispositions, intergenerational transmission, life orientation, the quality of the pregnant woman's relationship with her own mother (Kornas-Biela 1992, 249-257). The maternal attitude revealed by the woman is also crucial. Mothers that control the child's development are less likely to communicate with the child, are more restrained in their positive assessment of the child's competences and strive to maintain their current lifestyle (Bielawska-Batorowicz 2006, 115-116). Development facilitating mothers, in turn, derive greater joy from motherhood, adapt more easily to the demands of the pregnant state, attribute great importance to the development of paternal attachment, initiate prenatal interaction with the child sooner and more readily appreciate the child's communicative competence (Bielawska-Batorowicz 2006, 115-116).

Similarly, the formation of the paternal bond develops gradually in accordance with specific developmental phases (Kornas-Biela 2002, 72-89). The first of these covers the time between the father being informed about the expected conception of the child and its confirmation. The second stage, which is the longest in terms of time, includes the process of personalisation of the child, acceptance of paternal identity and adaptation to the parental role. The third stage comprises the immediate preparation for childbirth. In each of the aforementioned phases the father executes his own developmental tasks towards both his partner and the child. The scope and degree of paternal bonding is determined by the experiences of the generational family, the quality of the relationship with his own father or his absence in the process of upbringing, the circumstances of child's conception, procreation plans, value system, psychological integration, life orientation, material stability, the quality of the re- 
lationship with the child's mother, satisfaction with marital and family life and so forth. (Kornas-Biela 2009, 95-101; 2002, 72-89). Fathers adopting the type of parental attitude defined as participatory undertake prenatal communication with the child, personalize its person, emotionally support its mother, engage in strengthening the partnership relation and are receptive to fulfilling caregiving roles (Bielawska-Batorowicz 2006, 127-128). Fathers with a predominantly observational type of attitude experience more difficulties in establishing prenatal interaction with the child. They are also less concerned about the mother's needs and show little interest in the course of pregnancy (BielawskaBatorowicz 2006, 127-128).

The prenatal bond is embodied in prenatal dialogue, which is also its essential developmental factor. This dialogue is commonly understood as a communicative interaction between parents and their child in the advanced stages of pregnancy. In fact, its initiation commences actually in the preconception period. The initial stage of prenatal dialogue takes place when parents decide to conceive a child. The conditional stage occurs at the time of the marital union conducing to conception. The third, unconditional stage extends from the successful conception to the whole period of the child's prenatal development (Fiałkowski 1996, 64).

The quality of parental attachment is one of the key predictors of parents' attitudes towards obstetric failure, the miscarried child and the issue of arranging its funeral (Guzdek 2017, 241). The intensity of experiencing procreative loss is compared to the intensity of psychological and spiritual suffering experienced after the death of a close family member, with whom the bereaved person had a strong emotional bond (Czarnecka-Iwańczuk 2010, 1174). For parents, the loss of a child at any stage of parental attachment development is a traumatic event determining a situational psychological and spiritual crisis, temporarily destabilising their psychological and life balance (Pikus 2014, 44). It constitutes a natural reaction of a healthy person to a traumatic event that exceeds their mental resources and adaptation capabilities, as well as the previously developed mechanisms of coping with a difficult situation (Bielan, Machaj and Stankowska 2010, 42; Mroczkowska 2011, 77).

This crisis in normal conditions lasts from 6-8 weeks (Bielan, Machaj and Stankowska 2010, 42). Miscarriers experience strong and dynamic cognitive, emotional and behavioural consequences of miscarriage during this period (Łuczak-Wawrzyniak, Czarnecka-Iwańczuk, Bukowska and Konofalska 2010, 375). They may be experienced immediately after the procreative loss as various symptoms of mourning or have a distant character in the form of anxiety, psychotic and depressive states (Mroczkowska 2011, 78). For most parents, miscarriage is perceived as a pointless event that disintegrates their value system (Murlikiewicz and Sieroszewski 2013, 93). The essence of grief 
accompanying miscarriage is anchored in a strong focus on the unfulfilled, although expected, parental role and the imagined relationship with the deceased child and his or her person (Murlikiewicz and Sieroszewski 2013, 93). In clinical practice, more and more attention is paid to the non-somatic effects of spontaneous miscarriages, taking into account, in the therapeutic procedure conducted after the hospital treatment, the legitimacy of psychological, and if necessary also psychopharmacological support of the bereaved parents (Lewicka, Sulima, Pyć and Stawarz 2013, 127; Jakiel, Robak-Chołubek and Tkaczuk-Włach 2006, 193).

The key condition for the development of the prenatal bond and the disclosure of parental reactions after miscarriage, which are adequate to the death of the closest person, including a person with such a special position in the family system as a child, is the prior receptive recognition and actual interiorisation of the ontic and ethical subjectivity of the fetus by the people experiencing miscarriage. What is particularly important is the affirmation of the child for its own sake, that is as a person who is an autotelic value, and not so much the approving recognition of the conception and acceptance of the child on the grounds of the various types of values identified in it or expected from it with the omission of its fundamental value as a subject. Ontological-axiological personalology guided by the ethical principle of the value (sanctity) of life leads to a fourfold argument for the foetal conception personalisation correlating with granting it the status of a child in the family. This argument is composed of four minor ontological assumptions referred to with the acronym SCIP: Species, Continuity, Identity and Potentiality (Eisenberg and Schenker 1997, 18-19). The personal ontic identity of the foetus identified and justified in this way is the basis for the formation of the parental attitude in the course of the child's prenatal development in all its components that include cognitive, axiological, emotional-affective, spiritual-religious and behavioural-actional ones (Dudziak 2009, 59-68). For the duration of pregnancy, parental attachment manifests its multidimensional form corresponding to the indicated components of parental attitude. Similarly, procreative loss entails specific consequences at particular levels defining the multi-level structure of parental attitude. In the cognitive dimension, parents identify miscarriage as a traumatising event of the death of a human person and the premature passing of a family member with a special status (Holub 2013, 11-22). In the axiological aspect, they affirm the moral obligation to show reverence to the corpse or remains of the child and to externalise the mourning in order to confirm its personal dignity in the social community (Kieniewicz 2012, 195-2012). At the emotional-affective level, they may strive to constructively work through parental bereavement before attempting to conceive another child (Dziedzic 2013, 153-173). In the spiritual-religious sphere, in the process of mourning they 
refer to the accepted system of religious meanings to strengthen the marital bond and to give the loss a new hermeneutic quality and spiritual continuation of the bond with the child in the perspective of its post-mortem fate (Guzdek 2020b, 21-37). In the behavioural-activity area, they organise, as far as the clinical situation allows, a family funeral for the miscarried child and cultivate its memory in family relations by means of various symbolic forms shaping the historical memory of the family (Guzdek 2019, 359-426). In the remainder of this study, more attention is paid to the emotional-affective component of parental attitudes regarding the psychological consequences of clinical miscarriage and the psychosocial support of miscarrying parents.

\section{The context of the psychological consequences of procreative loss}

Differentiation of parents' reactions to obstetric failure results, according to the assumptions of Aaron Antonovsky's salutogenetic concept, from the bereaved's subjective evaluations of the loss episode and the meanings attributed to it, from the spouses' own resources and their ability to use them in coping with the crisis situation (Barton-Smoczyńska 2008, 77). The effectiveness of the healing process correlates to the degree of utilisation of internal and external resources with optimising the parents' level of functioning and their adaptation to the new reality after the loss (Barton-Smoczyńska 2008, 78). The effectiveness of the healing process depends on the degree to which internal and external resources are used in optimising the parents' level of functioning and their adaptation to the new reality after the loss (Barton-Smoczyńska 2008, 78). The course of the spouses' adaptation to the experience of the child's death may be affected by the cause of the miscarriage (whether it is located on the side of the child or the parent), the circumstances of the miscarriage (whether the loss occurred suddenly, whether the parents were informed about the risk of pregnancy), previous obstetric failures, previous problems in accepting life failures, unfavourable financial, professional or family situation, as well as the lack of support from the generational families of the spouses and the closest relatives (Kornas-Biela 1993, 64-65).

Parents have four essential tasks to perform in order to successfully complete the grieving process after miscarriage. These include accepting the fact of the child's death, allowing themselves to experience pain and grief, adapting to the new life situation and restoring the emotional balance in the marital relationship (Czarnecka 2005, 11). They correspond to consecutive stages of mourning which include the stage of shock and behavioural disorganization, self-protection through denial and suppression, awareness of loss, experiencing grief and sorrow, regaining control over 
life as well as adaptation and new orientation (Czarnecka 2005, 10; Łuczak-Wawrzyniak, Czarnecka and Bukowska 2012, 48-49). Some parents appreciate the value of life of the miscarried foetus only after the procreative loss (Łuczak-Wawrzyniak, Czarnecka-Iwańczuk, Bukowska and Konofalska 2010, 376). Researchers do not concur with regards to the frequency of bereavement in women with procreative failure in early pregnancy (Kornas-Biela 1999, 180). The gender-different intensity of parental attachment, especially in terms of its physical analogue in the first weeks of prenatal development, may translate into significant discrepancies in the intensity of mourning by both parents after prenatal loss (Broquet 1999, 12). A premonition of bereavement even before the loss of the child is possible, provided that the patient was informed about the risk of miscarriage (Kornas-Biela 1999, 180). Caution is needed when diagnosing depressive disorders in bereaved people. Difficult emotional states and psychosomatic reactions natural for the course of mourning cannot be unreflectively identified with depressive symptoms (Prażmowska, Puto, Kowal and Gierat 2009, 53). The symptoms may overlap, however, and prenatal loss determines the high probability of occurrence of both bereavement and depression. Hence, a differential diagnosis is indispensable should the alleged mourning process take on pathological features such as psychomotor retardation, considerable sense of worthlessness, suicidal thoughts, severe sleep disorders, significant impairment of social functioning, alcohol abuse, etc. (Broquet 1999, 14).

Psychosomatic experiences of women after miscarriage are marked by dynamic processuality of changes in terms of time of disclosure and strength of intensity. In normal mourning, difficult emotional states gradually give way to positive adaptation. The time scope of healing is individualized and may last from two weeks to a year, however, in cases of complicated mourning the time scope is substantially longer (Sikora 2014, 47). The course and intensity of the mother's experience after miscarriage is conditioned, in addition to the resources at hand, by the circumstances co-occurring with the loss and the possibility of learning the cause of the obstetric failure. Marital crises or family conflicts accompanying miscarriage may, as a cumulative effect, trigger acute depressive states (Sikora 2014, 47). The severity of emotional pain and its impact on the day-to-day functioning correlates with the duration of the lost pregnancy, previous obstetric failures, comorbid mental or psychiatric problems and the support system available to the bereaved mother (Broquet 1999, 13).

Women's reactions to the experience of miscarriage provide a basis for distinguishing three basic groups of patients namely mothers with pronounced mental disorders occurring in those women who strongly desire offspring, women with moderate problems usually resulting from tremendous pressure of 
the external environment and mothers who do not disclose their disorders and usually do not accept the fact of conceiving a child (Kryszkowski, Karowicz-Bilińska, Florkowski and Gałecki 2012, 99).

As a result of the chronic stress experienced by the patient during her miscarriage, a post-traumatic stress disorder may occur. This disorder develops in the aftermath of a traumatic experience in which the patient directly faced a serious threat to her own health and the death of a person emotionally significant to her (Szymona-Pałkowska 2005, 52; Steuden and Janowski 2016, 551 ). In nearly $60 \%$ of mothers, symptoms of acute stress disorder [ASD] are observed in the first two months after miscarriage. In about $40 \%$ of women who have miscarried, features of post-traumatic stress disorder [PTSD] are observed (Barton-Smoczyńska 2008, 80). Significant factors for higher levels of anxiety, the occurrence of depression and post-traumatic stress disorder after miscarriage include the mother's highly anxious personality, emotion-focused coping style, higher rates of neuroticism and previous procreative losses (Murlikiewicz and Sieroszewski 2013, 96). No relationship was found between women's age, gestational age, and higher frequency of depressive symptoms and PTSD symptoms. On the other hand, it was proven that an extroverted personality and openness to new experiences is a predictor that significantly protects the mother (Murlikiewicz and Sieroszewski 2013, 96). There is no convincing research to consider the presence of an older child as a variable inhibiting the development of symptoms of depression or severe sadness (Broquet 1999, 13). Ignoring the crisis and not undertaking efforts to restore the patient's state of equilibrium may lead to the development and perpetuation, for many months or years, of labile emotional states which, in the case of the inevitable impact of other stressors at subsequent stages of procreative and family life, make the mother more susceptible to the occurrence of a secondary crisis state (Bielan, Machaj and Stankowska 2010, 42). Depriving the patient of psychological care and social support from the father of the child and the generational family, compensating for the deprivation of emotional needs of the mother after the procreative loss, constitutes an increased risk factor for the development of psychopathological forms of mourning. Cases of suicide by women after clinical miscarriages were noted (Jakiel, Robak-Chołubek and Tkaczuk-Włach 2006, 193). The repulsive manner of hospital care for a miscarrying mother can lead to relational trauma (Landwójtowicz 2019, 162-168). Post-traumatic stress disorder, together with compulsive behaviours, anxiety disorders, panic attacks and depression, are the most frequent psychiatric consequences of pregnancy loss (Czarnecka 2005, 11). Obsessive-compulsive disorders, memory disorders and breakdown of the mechanisms of aggression control are less frequently diagnosed (Kryszkowski, Karowicz-Bilińska, Florkowski and Gałecki 2012,99). Failure to accept grief and the activation 
of defence mechanisms towards denial of the consequences of miscarriage generate high health costs not only in the emotional sphere, but also in the quality of life of the mother after the loss, in extreme situations leading to puerperal psychosis (Bielan, Machaj and Stankowska 2010, 43). Psychoses are relatively rarely diagnosed after miscarriages (Kryszkowski, Karowicz-Bilińska, Florkowski and Gałecki 2012, 99). The literature reports cases of pseudo-pregnancy accompanying PTSD after spontaneous miscarriage (Grzyb 2014, 94-98).

The initial stages of working through the procreative loss by the woman are dominated by sadness and grief, a sense of injustice, helplessness and internal emptiness, reactions of searching for the deceased, longing for the child or a desire to get pregnant again at the earliest opportunity (Łuczak-Wawrzyniak, Czarnecka-Iwańczuk, Bukowska and Konofalska 2010, 375; Chrzan-Dętkoś 2010, 27). The period of particular risk of depressive symptoms, generalised anxiety and panic includes the first twelve weeks after the prenatal loss (Broquet 1999, 13). Mothers struggle with lack of self-acceptance and low selfesteem. They question their procreative potential and deny their ability to give birth to a living child. They blame themselves for past miscarriages. Guilt is one of the most common and longest-lasting symptoms after miscarriage. Its intensity is amplified if the maternal etiology of miscarriage has been identified or if in early pregnancy the patient experienced a marked ambivalence towards unplanned conception (Broquet 1999, 12). Women feel shame comparing themselves to mothers from their own environment who have given birth to live and healthy children. Crying is a natural way of relieving emotional tension and plays an important cleansing role. Mothers may experience fear of coming into contact with the remains of the miscarried child. On the one hand, they are distressed by the physiognomy of the immature foetus, on the other hand, by the need to cuddle and say goodbye to the child (Bielan, Machaj and Stankowska 2010,46). Emotional reactions are concomitant with somatic symptoms of the crisis such as sleep disorders, choking, tightness in the throat, shortness of breath, fatigue, the feeling of emptiness in the abdomen, inability to work, and so forth (Guzewicz 2014, 17-26). The specificity of maternal bereavement is the orientation towards internal experiences (Łuczak-Wawrzyniak, Czarnecka and Bukowska 2012, 49).

In ongoing studies, mothers point to religious references as a significant factor in coping with loss, which by no means excludes a religious crisis. Patients who have lost a child through spontaneous miscarriage perceive the child differently from pregnant women who have had an abortion. Some women who have had a spontaneous miscarriage confirm that they maintain a spiritual relationship with their child after its death through naming and imagining it. In turn, mothers who decide to terminate their pregnancy relate to the aborted 
child with hostility and fear, not establishing an elementary emotional bond with it (Szymańska and Chazan 2004, 11,13; Pikus 2014, 44).

Clinical miscarriage substantially reduces the quality of life of patients in relation to its subjective assessment expressed by women who have not lost pregnancy. There is an evident change in the sense of quality of life conditioned by duration of time since the miscarriage. The longer the time since the miscarriage, the higher the quality of life is. Variations in women's satisfaction are related to the number of children they had before the miscarriage occurred or the absence of children. Mothers with experience of miscarriage of the first pregnancy assess life satisfaction worse than women without children (Mroczkowska 2011, 81-82).

More than $80 \%$ of women experiencing miscarriage start trying to conceive another child less than 6 months after the miscarriage (Barton-Smoczyńska 2008, 80). The second pregnancy before the lapse of a year from the previous loss significantly complicates the psychological situation of the mother who experiences two conflicting psychological processes: uncompleted mourning after the first child and opening up to conception and the development of parental attachment to the second child (Barton-Smoczyńska 2008, 80). It not infrequently results in the suppression of emotional reactions characteristic of the stage of mourning and inhibition of the development of the prenatal bond with the newly conceived child due to the unprocessed fear of its miscarriage (Barton-Smoczyńska 2008, 80; O’Leary and Gaziano 2011b, 247). The loss of a child as a result of spontaneous miscarriage and the failure to close the bereavement associated with it may therefore affect maternal attachment to successively conceived children and impinge on the way they are raised, as evidenced in clinical practice by the foster child syndrome or the protected child syndrome identified (Murlikiewicz and Sieroszewski 2013, 93; O’Leary and Gaziano 2011b, 268). Some women after procreative loss struggle with the so-called empty arms symptom, especially when the miscarriage occurred in an already advanced pregnancy (Pikus 2014, 44). Anxiety and depressive symptoms after miscarriages can take the form of perennial ailments and persist also after the birth of healthy children (O'Leary and Gaziano 2011b, 247).

After the loss of a child through clinical miscarriage, men may experience feelings and emotions analogous to those of women who miscarry, although the intensity of grief and anxiety is usually relatively lower and the duration of occurrence shorter than for mothers (Chavez, Handley, Jones, Eddy and Poll 2019, 665). It is not uncommon for fathers, responding to the expectations of the environment, to pose the attitude of a strong man standing steadfastly by the side of the woman, while at the same time, inside, experiencing helplessness and being left out of the side-lines of the entire event of child loss with the dominant focus of the environment on the emotional state of the 
mother (Murphy and Cacciatore 2017, 129-134). Men demonstrate difficulty in sharing their emotions. They mask their pain and do not communicate their own needs, thus trying to help their partner without burdening her with their emotional condition. As a result, they do not receive adequate support, which correlates with feelings of loneliness, isolation, marginalization of their grief, confusion, and being overwhelmed by intense emotions (Chavez, Handley, Jones, Eddy and Poll 2019, 674-675). Fathers may also exhibit feelings of guilt arising from the conviction that they may have contributed in some way to the child's death such as initiated sexual contact with their partner. Self-blame is not infrequently associated with feelings of inability to protect the spouse from miscarriage and lack of competence to adequately accompany her after the loss. The man gives himself more consent to violent emotional reactions (outbursts of anger, rage) in private than to the public expression of his grief. Despite not externalising difficult emotional experiences in front of the partner, women forming a deep marital relationship perceive non-verbal symptoms of a strong course of mourning in the husband. A significant number of mothers, in their conversations with their partners, focus on the circumstances of the miscarriage and their own emotional experiences, without trying to channel their attention to the man's need to verbalize the experiences and significance he has given to the event of loss. After accompanying their partner for a longer period of time, men adopt a task-oriented attitude by engaging in professional and household duties. The specificity of father's bereavement is an instrumental approach expressed in increased activity and strong involvement in solving the problem of loss more from the logical-rational side than from the emotional side (Sikora 2014, 49-50; Łuczak-Wawrzyniak, Czarnecka and Bukowska 2012, 49-50).

About $70 \%$ of married couples struggle with relational difficulties after miscarriage. Nearly $40 \%$ of marriages break up after the loss of the first pregnancy (Barton-Smoczyńska 2008, 80). Marital problems most often have their source in inadequate communication and lack of understanding of the sexual differentiation of the grieving process reinforced by individual personality dispositions of the spouses and their different strategies of coping with the crisis. Thus, women's open emotional expression is accompanied by men's affective distancing, which in the absence of awareness of the natural condition of incommensurability of the expression of grief by spouses may give rise to mutual accusations of a lack of attitudes adequate for mourning on the part of the man or excessive affective reactions on the part of the woman (LuczakWawrzyniak, Czarnecka and Bukowska 2012, 49-50). Negative relational consequences of miscarriages include the inability to talk about the loss, the partners' resignation from communicating their needs, the feeling of being neglected by the partner who does not externalise their feelings, projecting dif- 
ficult emotions on the spouse, withdrawal from the relationship or its break-up (Murlikiewicz and Sieroszewski 2013, 93; Kornas-Biela 1999, 180-191). Marital conflicts may also stem from limitations in the sexual relationship. The psychosexual effects of procreative loss on the part of the woman include decreased libido, lowered sense of sexual attractiveness, fear of vaginal penetration, vaginismus, dyspareunia, sexual aversion, sexual disharmony, orgasmic dissociation, sadness after intercourse and self-aggression (Bielan, Machaj and Stankowska 2010, 45-46). The atrophy of the relationship with the spouse, the deficit of satisfaction of emotional needs, overt rejection and a deep sense of hurt may lead to relational trauma in a married couple (Landwójtowicz 2019, 162-168).

Parents experiencing a period of grief often unconsciously downplay the needs of older children, causing them to experience a double loss: the death of a sibling and a weakening of their relationship with their parents (O'Leary and Gaziano 2011, 174; Murphy and Cacciatore 2017, 129-134). Children's emotional reactions to the death of a loved one are varied. They can manifest as shock and denial, aggression and rebellion, withdrawal and apathy, disorders of sleep and appetite, exaggerated attraction to others and feelings of loneliness. The child often blames themselves not only for the death of the deceased, accompanied by strong fears for the lives of other family members, but also attributes to themselves responsibility for parental disagreements or an overt marital conflict. The causes of child bereavement disorders may result from the environment's failure to perceive the child's emotional reactions and deprivation of the child's need for security, from the child's personality traits and lack of necessary support from the family community as well as from the traumatic circumstances of the death of the loved one. The situation becomes more complex when the tragic event for the family is not understood, which is compounded by fictitious explanations given to the child as well as by the child's imitation of the parents' abnormal behaviour, especially the attitude of denying the fact of death and suppressing emotions (Herbert 2005, 30-31, 48-52). An important element of support for bereaved siblings is reassurance from parents about their unchanging importance and the equal position of all children in the family (O'Leary and Gaziano 2011b, 249). This is because siblings can clearly perceive, and emotionally directly experience, significant, sometimes permanent changes in the family's emotional and relational balance following prenatal loss as a result of the parents' emotional separation. Disempowerment in the face of one's own parental bereavement and inability to come into direct contact with one's emotions is not infrequently associated with an attitude of helplessness on the part of partners in the face of the grief of older children. The erroneous common belief that siblings are unable to understand the fact of death and experience it at an emotional level due to their young age means that 
their grief is ignored and parental communication in this aspect is neglected (O'Leary and Gaziano 2011a, 174, 190-191). Older children should not be excluded from the ritual of farewell and deprived of participation in the funeral of the deceased, but, on the contrary, additional forms of expression of grief, sorrow and love towards the lost child, adapted to the age and sensitivity of the individual members of the siblings, should be developed in addition to the officially performed rituals (Murphy and Cacciatore 2017, 129-134).

A family grappling with the grieving process after the death of a child generally adopts one of three strategies for working through the crisis situation. The role of the deceased may remain vacant. The family system may look for a replacement member by making efforts to conceive another child as quickly as possible. The role that the lost child was meant to play in the family community may also be assumed by one of the current family members. In the most drastic variant family bonds may be destroyed (Bielan, Machaj and Stankowska 2010,45). The prenatal death of a child burdens the whole family system and incurs emotional consequences felt in further generations (O’Leary and Gaziano 2011a, 191).

In order to work through procreative loss, a constructive entry of the parents into the mourning process while still in the maternity ward is essential. The accompaniment of the hospital medical professionals and the attending physician during the ongoing gynaecological care is of considerable importance in this respect. Strong support given to the miscarrying mother, in addition to individual resilience to stressful events, is a major factor in protecting the bereaved from developing the long-term psychosocial consequences of obstetric failure. Not infrequently, miscarriage is a socially unacknowledged loss, whose intrinsic value to the parents is invalidated in their relationship with the environment (Murphy and Cacciatore 2017, 129-134).

\section{Procreative loss in the context of social support of medical professionals}

The conviction that professionalism excludes all emotional references of the medical professionals to the miscarrying patient is not only fundamentally false, but in practice impossible to implement. The professionals, while providing biomedical information to the mother, always formulate messages about their own emotions and affective attitude towards the interlocutor in a more or less conscious way (Szymańska 2012, 45). One cannot fail to communicate emotions. The affective message intentionally excluded at the verbal level is complemented at the non-verbal level. The ostensible distancing from the patient's emotional state and strong restriction of the expression of one's own emotions in a communicative relation is a manifestation of actual 
emotional rejection of the interlocutor. The rejection will be interpreted not so much by the patient through intellectual cognition, but mainly through affective cognition. The potential of cognitive perception is significantly reduced in the experienced crisis even when the person's intellectual resources are high. Patients in a mental crisis natural to miscarriage perceive and interpret the surrounding reality primarily on the emotional plane, and only later on the cognitive plane. This is confirmed by numerous testimonies of mothers regarding inappropriate behaviour of midwives and doctors (Kolska 2010, 7-20; Wyka 2010, 81-90). The reported cases did not necessarily involve deliberately designed reprehensible behaviour or inappropriate verbal communication. The failure to show an attitude of emotional affirmation towards the patient and her family is in fact often the basis for the formulation of accusations of cold routine, haste and deficit of necessary empathy. The lack of emotional involvement, so far considered a sign of professionalism, is now becoming the reason for negative assessment of the medical professionals' communication with patients. However, it is essential to define the scope and inviolable limits of this involvement, in other words to formulate a specific emotional discipline of the medical team, each time conditioned individually, also by the personality dispositions of its members. Such discipline, though, should not be understood as emotional distancing, but as a balanced level of affective expression which, on the one hand, satisfies the need for empathic accompaniment of the person seeking this form of support and, on the other hand, maintains a relatively stable emotional equilibrium of the supportive person themselves. The delineation of emotional discipline by each member of the treatment team seems to be a prerequisite for the psycho-prevention of professional burnout.

The midwife's first contact with a pregnant woman in danger of miscarriage generally consists of a skilful conduct of a detailed obstetric and gynaecological interview. Its aim is not only to identify the observed symptoms of complications of the current pregnancy, but also to collect data on previous gynaecological operations and obstetric failures, the course of previous pregnancies and the menstrual cycle as well as the methods of fertility control used. Information on chronic diseases and infections coexisting with pregnancy, on lifestyle and workload, on preferred diet and stimulants is also important. The midwife should clearly and comprehensibly present to the mother the initial steps to be taken in the therapeutic procedure and obtain her consent to their implementation. The adaptation of the language of communication to the intellectual level of the mother is the primary principle of effective communication as a basic tool to reduce the level of stress experienced by patients. Although the subject of the interview concerns biomedical issues, at the same time it should be utilised to correctly assess the mother's emotional condition and identify her psychosocial needs. The midwife should pay particular atten- 
tion to the way the mother relates to the unborn child and to the vocabulary she uses to define the child's identity. This will provide a preliminary assessment of the degree of maternal attachment development, which is extremely important in order to properly target the language of communication that medical professionals will use with the mother and to verbalise information about the child's condition. Consistency between staff attitudes and the mother's expectations of how staff will relate to the prenatal child is crucial. These observations should necessarily be shared by the midwife with other members of the medical team so that they present a relatively consistent attitude towards the mother and her baby. The role of the midwife is to prepare the pregnant woman for the planned medical procedures, respecting her intimacy and sensitivity. The initial contact with the patient should therefore instil confidence in the staff. This will be achieved if the midwife endows the mother with an attitude of openness and expresses willingness to actively accompany her through the difficulties of hospitalization, not only in the role of a professional with high qualifications in obstetrics, but also as a person supporting the mother in the psychosocial dimension of the experienced loss (Mach, Nowacka and Dmoch-Gajzlerska 2014, 34; Chrzan-Dętkoś 2010, 27-29).

One of the basic instruments for supporting the patient is to communicate with both parents and to facilitate contact between the patient and her relatives. In doing so, the parents become equal partners in the dialogue with medical professionals, thus relieving the patient of the responsibility of passing on information to her partner. This would put the pregnant woman in the role of having to explain the situation to the father. The parents expect an intelligible explanation of the diagnosis, the planned treatment methods, the next steps in the procedure, an indication of possible complications, steps after leaving hospital and the chances of giving birth to a healthy child in the future. The pivotal role of the obstetrician is to discuss the possible causes of the miscarriage and to relieve the parents of an unjustified sense of guilt. During the conversation with the bereaved, eye contact and an attitude of attentive listening to the parents are important. This involves making the spouses feel safe and expressing readiness to answer the questions they want to ask. Psychologically, the situation of a doctor communicating information about the death of a child to the parents is by far the most difficult. The partnership dialogue of the treatment team with both spouses urges the parents to give each other support within the marital relationship and to search together for strategies to work through the experienced loss (Barton-Smoczyńska 2010,120; Hennel-Brzozowska 2010, 59-68; Murphy and Cacciatore 2017, 129-134).

Pregnant women at risk of miscarriage or subject to medical procedures after the intrauterine death of the baby has been established must not be admitted to a gynaecology or obstetrics ward together with mothers preparing for child- 
birth or nursing their new-borns. The hospital's work logistics should provide for a pregnancy pathology ward with separate rooms for women experiencing miscarriage. These rooms should have separate sanitary facilities so that mothers do not come into contact, even in this aspect, with women in a normal pregnancy. Exposure of a patient at risk of miscarriage to the sight of newborns and mothers connected to an ECG machine intensifies the pathomechanism of miscarriage. The patient should be acquainted with the topography of the ward, the work rules of the treatment team and the visiting hours by the family. A place conducive to a sense of intimacy for meetings between the pregnant woman and the father of the child and the extended family should also be prepared (Mach, Nowacka and Dmoch-Gajzlerska 2014, 34).

Stillbirth in advanced pregnancy is a particularly traumatic event. Allowing the father to participate in the delivery, if both parents wish, is a matter of unquestionable significance for the psychological consequences of the quality of hospital care implemented for stillbirths. Positive effects of the partner accompanying the parturient have not only a psychosocial dimension, but also a psychophysiological one. The duration of labour is reduced. Pregnant women experience lower levels of labour pain, anxiety and exhaustion. The amount of anaesthetic administered to the parturient is also lower. Mothers may attribute greater value to the presence of the father than to the midwife (Kaniok 2011, 34-35; Szymona-Pałkowska 2005, 40).

Patients at risk of miscarriage who received bed rest treatment require particularly attentive care. Pointing out the medical premises justifying an absolute bed rest regime is extremely important. Tensing the abdominal muscles while sitting or straightening up has a stimulating effect on the contractile activity of the uterus. Rest reduces the number of noxious stimuli emitted by the central nervous system, thus improving the blood supply to the uterine muscle. Bed rest treatment necessitates taking care of all physiological needs in bed and eliminating movement, which may negatively affect the patient's emotional state. Providing the mother with comfortable personal hygiene conditions and ensuring the cleanliness of bed linen requires great sensitivity and tact from the staff. Verticalisation when the miscarriage symptoms have subsided is a gradual process. Its effects depend on the midwife's dedication to careful observation of treatment progress and patient assistance (Mach, Nowacka and Dmoch-Gajzlerska 2014, 35).

During the diagnostic process, the doctor should not arbitrarily reject the parents' request for follow-up consultations or repetition of tests to confirm the miscarriage. After communicating the unequivocally stated diagnosis of the child's death, the parents should be given time to accept the information they have heard and to emotionally recuperate. If there was a live miscarriage, the baby should be placed in an incubator and the parents should be allowed 
to accompany the baby until its death including the opportunity to administer baptism with water. The erroneous practice of removing traces of the child's presence, diverting the parents' attention from the fact of the child's death, and denying the bereaved contact with the child's corpse or remains must be rejected. Staff should adopt the attitude of tactful accompaniment to the parents at the farewell meeting, for which they should be prepared in advance. Parents often fear the physiognomy of the deceased child therefore staff should patiently inform them of what to expect when they meet the dead child. It is fundamental to take care of the right place, time and conditions of the farewell (Bronka, Gościcka-Kmieć, Nagórko and Zaleska-Skup 2012, 83-89).

The obstetric care team must familiarise themselves with the training materials prepared by psychologists, midwives and parents after a loss. These studies show a number of appropriate guidelines for doctors and midwives to communicate with a patient who is experiencing miscarriage and her partner. The Association of Parents After Miscarriage has drawn up a 'Miscarrying in a humane way' Decalogue urging medical professionals to obey the following rules:

"1. Show respect for the mother and the deceased child.

2. Conduct necessary examinations in an intimate setting

3. Allow the husband to assist with gynaecological examinations, ultrasound examinations and curettage until the patient falls asleep.

4. Keep clerical matters to a minimum, data can be completed later or the patient's husband can be asked to do it.

5. Always perform the curettage under general anaesthetic.

6. Provide the mother with psychological support.

7. Facilitate access to full medical information.

8. Inform the patient of all actions that will be taken.

9. Place the bereaved mother in a room without pregnant patients, so that she does not listen to the heartbeat of other babies during the ECG and the stories of joyful expectation.

10. Allow the parents to say goodbye to the baby in accordance with their conscience. Inform about the right to burial, about what will happen to the baby's body. Help to collect souvenirs of the child [ultrasound pictures, record of the child's pulse, footprint, photo of the child]" (Bronka, GościckaKmieć, Nagórko and Zaleska-Skup 2012, 88-89).

The employment of a psychologist in the hospital ward is a desirable solution (Sikora 2014, 54). That person's work has the nature of crisis intervention, which should encompass both parents. Its aim is to immediately counteract the emotional, cognitive and behavioural consequences of miscarriage in as much as it is possible. In most cases, the short-term stay of the patient in the ward necessitates emergency measures which, if necessary, should be 
continued as part of the psychotherapy carried out after the end of the hospitalisation in mental health clinics available. The therapeutic relationship in crisis intervention should be based on the recognition of coping strategies used so far, acceptance of the emotions experienced, strengthening communication with the environment, raising hope, etc. The importance of the presence of a psychologist in maternity and pregnancy pathology wards cannot be overestimated for the formation of positive language and behavioural patterns in the communication of medical professionals with miscarrying parents and for the psychoprophylaxis of burnout among team members (Łuczak-Wawrzyniak, Czarnecka-Iwańczuk, Bukowska and Konofalska 2010, 376).

The obstetrician-gynaecologist providing ongoing care to the patient is particularly well placed to continuously monitor her psychological well-being for the exclusion of symptoms of depression or anxiety syndromes in the 12-18 months following a miscarriage. An important diagnostic role in this regard is played by a detailed clinical interview conducted during follow-up visits, as well as the use of professional scales for screening. It is necessary to inform the patient and her partner about the natural grief experienced after the loss, to orientate the partners to mutual support and companionship, to relieve the guilt of the miscarriage, to patiently explain the doubts, to provide materials on the psychosocial consequences of miscarriage, to monitor the symptoms of suicidal crisis, to indicate the diagnostic possibilities of the aetiology of miscarriage and to determine the potential chances of a live birth (Broquet 1999, 14-15).

\section{Conclusion}

On the basis of the analyses conducted, it is concluded that the anthropological context of clinical miscarriage is crucial for determining the specificity of this type of human death. In no other circumstances of the death of a human being does the anthropological status of the dying subject determine to such a decisive extent the typology of characteristics of the thanatic event and its multiple ramifications. The dissimilar interpretations of the anthropological position of the miscarried foetus result in contrasting symbolic narratives about the loss, either based on the cultural script of the death of the child, or not identifying obstetric failure with the death of the human subject at all. The relational (prenatal bond), psychological and assistive contexts depend significantly on the principled judgment of the anthropological status of the miscarried foetus. 


\section{PORONIENIE KLINICZNE Z PERSPEKTYWY WIELORAKICH KONTEKSTÓW STRATY PROKREACYJNEJ}

\section{STRESZCZENIE}

Fenomen poronienia klinicznego wzbudza coraz większe zainteresowanie badaczy z dyscyplin pozamedycznych. Choć nadal dostrzegalna jest znacząca dysproporcja pomiędzy obszerną literaturą traktującą o poronieniu spontanicznym z perspektywy medycznej w porównaniu do wzrastających liczebnie studiów prowadzonych w zakresie nauk społecznych i filozoficznych, to sukcesywnie postępuje proces zmiany orientacji badawczej wczesnych strat prokreacyjnych. Dominujące dotychczas jednostronne podejście biomedyczne ustępujące miejsca holistycznym ujęciom aksjomedycznym. Niniejsze studium wpisuje się w aksjomedyczny model poronienia klinicznego. Jego celem jest pogłębiona analiza czterech kluczowych kontekstów straty prokreacyjnej występującej na początkowych etapach rozwoju prenatalnego - antropologicznego, relacyjnego (przywiązania rodzicielskiego), psychologicznego i pomocowego. W rezultacie prowadzonych badań dochodzimy do wniosku, iż główną dominantą charakterystyk poronienia klinicznego jako zdarzenia tanatycznego jest płaszczyzna rozstrzygnięć antropologicznych statusu płodu i jego implikacji etycznych.

Słowa kluczowe: antropologia poronienia klinicznego, więź prenatalna, żałoba, etyka jakości życia, personalizm ontologiczny, personologia deskryptywna

Keywords: anthropology of clinical miscarriage, prenatal bond, mourning, quality of life ethics, ontological personalism, descriptive personology

\section{REFERENCES}

Bartnik, Czesław Stanisław. 2006. Szkice do systemu personalizmu. Lublin: Wydawnictwo KUL.

Barton-Smoczyńska, Izabela. 2008. "Rozwój więzi psychologicznej między matką a dzieckiem w ciąży prawidłowej i powikłanej". Życie i Płodność 4(2), 77-84.

Barton-Smoczyńska, Izabela. 2010. "Adaptacja kobiet po śmierci dziecka poczętego". In: Poronienie: zrozumieć rodziców po stracie, edited by Cyprian Klahs, 109-125. Poznań: Wydawnictwo Polskiej Prowincji Dominikanów "W drodze".

Bielan, Zbigniew, Anita Machaj and Izabela Stankowska. 2010. "Psychoseksualne konsekwencje straty dziecka w okresie ciąży i porodu". Seksuologia Polska 8(1): 41-46.

Bielawska-Batorowicz, Eleonora. 2006. Psychologiczne aspekty prokreacji. Katowice: "Śląsk” Wydawnictwo Naukowe.

Bielennik, Łucja, Joanna Preis and Mariola Bidzan. 2010. "Uwarunkowanie więzi emocjonalnej z dzieckiem w okresie prenatalnym w ciążach wielopłodowych i pojedynczych". Perinatologia, Neonatologia i Ginekologia 3(3): 223-231.

Biesaga, Tadeusz. 2002. "Pojęcie osoby a zasada jakości życia we współczesnej bioetyce”. In: Ocalić cywilizację - ocalić ludzkie życie, edited by Zbigniew Morawiec, 53-63. Kraków: Wydawnictwo Księży Sercanów “SCJ”. 
Broquet, Karen. 1999. "Psychological reactions to pregnancy loss". Primary Care Update for OB/ GYNS 6(1): 12-16.

Bronka, Małgorzata, Kamila Gościcka-Kmieć, Monika Nagórko and Joanna Zaleska-Skup. 2012. "Ronić po ludzku - warunki ronienia w polskich szpitalach oraz postulaty ich zmian". In: Przegrane narodziny. Strata ciąży w aspekcie psychologicznym, socjologicznym, medycznym i etycznym, edited by Ewa Dmoch-Gajzlerska and Izabela Barton-Smoczyńska, 83-89. Warszawa: Oficyna Wydawnicza Warszawskiego Uniwersytetu Medycznego.

Callahan, Tamara, Aaron B. Caughey and Linda J. Heffner. 2004. Blueprints Obstetrics \& Gynecology. Malden: Blackwell Publishers.

Chavez, Megan S., Valerie Handley, Rebecca L. Jones, Brandon Eddy and Von Poll. 2019. "Men's experiences of miscarriage: a passivephenomenological analysis of Online data". Journal of Loss and Trauma 24(7): 664-677. doi.org/10.1080/23802359.2019.1611230

Chrzan-Dętkoś, Magdalena. 2010. "Utrata dziecka w okresie okołoporodowym - dobre praktyki szpitalne w opiece nad matką". Ginekologia Praktyczna 18(2): 27-30.

Ciach, Halina. 2013. Istota ludzka czy osoba ludzka? Krytyka bioetyki początków życia Petera Singera. Kraków: Wydawnictwo św. Stanisława BM.

Czarnecka-Iwańczuk, Marta. 2010. "Psychologiczne aspekty ciąży wysokiego ryzyka i sytuacji utraty ciąży". In: Ciąża wysokiego ryzyka, edited by Grzegorz H. Bręborowicz, 1165-1186. Poznań: Ośrodek Wydawnictw Naukowych.

Czarnecka, Marta. 2005. "Psychological aspects of miscarriage". Archives of Perinatal Medicine 11(4): 10-12.

Dudziak, Urszula. 2009. Postawy wobec wychowania seksualnego a hierarcha wartości nauczycieli. Studium teologiczno-pastoralne. Lublin: Wydawnictwo KUL.

Dziedzic, Jan. 2013. "Wsparcie psychologiczno-pastoralne w przeżywaniu żałoby po stracie dziecka”. In: Od bólu po stracie do nadziei życia. Pogrzeb dziecka poronionego, edited by Jan Dziedzic and Piotr Guzdek, 153-173. Kraków: Wydawnictwo Naukowe UPJPII.

Eisenberg, Vered H. and Joseph G. Schenker. 1997. "The ethical, legal and religious aspects of preembryo research". European Journal of Obstetrics \& Gynecology and Reproductive Biology, 75(1): 11-24. doi.org/10.1016/S0301-2115(97)00193-0

Fiałkowski, Włodzimierz. 1996. Ojcostwo na nowo odkryte. Pelpin: Wydawnictwo Diecezjalne.

Ford, Norman. 1995. Kiedy powstatem? Problem poczatku jednostki ludzkiej w historii, filozofii i w nauce. Warszawa: Wydawnictwo Naukowe PWN.

Gałuszka, Mieczysław. 2006. “Świętość życia versus jakość życia: na drodze ku spokojnej śmierci”. In: Problemy współczesnej tanatologii. Medycyna - antropologia kultury - humanistyka. Tom X, edited by Jacek Kolbuszewski, 19-27. Wrocław: Wrocławskie Towarzystwo Naukowe.

García-Enguídanosa, Angela, Maria E. Calle, Javier Valero, Sonsoles Luna and Vicente Domínguez-Rojas. 2002. "Risk factors in miscarriage: a review". European Journal of Obstetrics \& Gynecology and Reproductive Biology 102(2): 111-119. doi.org/10.1016/S0301-2115(01)00613-3

George, Robert P. and Alfonso Gómez-Lobo. 2005. "The moral status of the human embryo". Perspectives in Biology and Medicine 48(2):201-210. doi.org/10.1353/pbm.2005.0052

Goleń, Jacek and Katarzyna Urbańczyk. 2011. "Więź matki z dzieckiem w okresie prenatalnym”. Życie i Ptodność 5(1): 95-114.

Gorczyca, Jakub. 2014. Zarys etyki fundamentalnej. Kraków: Wydawnictwo WAM.

Grzyb, Izabella. 2014. "Pseudociąża w przebiegu zespołu stresu pourazowego po poronieniu - opis przypadku”. Psychoterapia 168(1): 93-98.

Guzdek, Piotr. 2017. Rozpoznaj swoje dziecko we mnie... Rzecz o poronieniu dziecka i jego pogrzebie. Kraków: Wydawnictwo Scriptum.

Guzdek, Piotr. 2019. "Pastoralne aspekty rodzinnego pogrzebu dziecka zmarłego na skutek poronienia klinicznego". In: Rodzina w społeczeństwie - relacje $i$ wyzwania, edited by Elżbieta Osewska and Józef Stala, 359-426. Kraków: Wydawnictwo Naukowej UPJPII. 
Guzdek, Piotr. 2020a. Kompendium pastoralne o rodzinnym pogrzebie dziecka martwo urodzonego i towarzyszeniu w żałobie osieroconej rodzinie. Kraków: Wydawnictwo św. Stanisława BM.

Guzdek, Piotr. 2020b. "Eklezjalny wymiar pogrzebu dziecka zmarłego bez chrztu w okresie prenatalnym. Perspektywa rzymsko-katolicka”. SOTER. Religious Science Journal 73(101): 21-37. doi.org/10.7220/2335-8785.73(101).2

Guzewicz, Monika. 2014. "Psychologiczne i społeczne konsekwencje utraty dziecka w wyniku poronienia". Civitas et Lex 1: 15-27.

Hennel-Brzozowska, Agnieszka. 2010. "Psychologiczna analiza sytuacji lekarza komunikującego pacjentce niekorzystne wyniki badań prenatalnych". Życie i Płodność 4(1): 59-68.

Herbert, Martin. 2005. Żałoba w rodzinie. Translated by M. Gajdzińska. Gdańsk: Gdańskie Wydawnictwo Psychologiczne.

Hołub, Grzegorz. 2010. Problem osoby we wspótczesnych debatach bioetycznych. Kraków: Księgarnia Akademicka.

Hołub, Grzegorz. 2012. "Człowiek a świat natury. Wokół koncepcji egalitaryzmu gatunkowego Paula W. Taylora". Logos i Ethos 32(1): 105-126.

Hołub, Grzegorz. 2013. "Godność osobowa dziecka nienarodzonego". In: Od bólu po stracie do nadziei życia. Pogrzeb dziecka poronionego, edited by Jan Dziedzic and Piotr Guzdek, 11-22. Kraków: Wydawnictwo Naukowe UPJPII.

Hołub, Grzgorz. 2016. "O dwóch spojrzeniach na istotę ludzką w początkach jej istnienia”. Studia Philosophica Wartislaviensia 11(3): 41-50.

Jakiel, Grzegorz, Dorota Robak-Chołubek and Joanna Tkaczuk-Włach. 2006. "Poronienia samoistne". Przegląd Menopauzalny 3: 191-194.

Kaniok, Przemysław E. 2011. "Znaczenie obecności mężczyzn podczas narodzin dziecka”. Życie i Plodność 5(4): 31-37.

Kieniewicz, Piotr. 2012. "Moralny obowiązek pogrzebania ciała ludzkiego wobec śmierci dziecka przed narodzinami”. Roczniki Teologii Moralnej 59(4): 195-2012.

Kolska, Katarzyna. 2010. "Jak pani może mówić o dziecku”. In: Poronienie, edited by Cyprian Klahs, 7-20. Poznań: Wydawnictwo Polskiej Prowincji Dominikanów "W drodze".

Kornas-Biela, Dorota. 1992. "Kształtowanie się przywiązania matki i dziecka w prenatalnym okresie jego rozwoju". In: Problemy wspótczesnej psychologii. Tom 1, edited by Adam Biela and Czesław Walesa, 273-278. Lublin: Polskie Towarzystwo Psychologiczne.

Kornas-Biela, Dorota. 1993. "Potrzeby rodziców po stracie dziecka w okresie okołoporodowym". In: $Z$ zagadnień psychologii prokreacyjnej, edited by Eleonora Bielawska-Batorowicz and Dorota Kornas-Biela, 61-75 Lublin: Redakcja Wydawnicza KUL.

Kornas-Biela, Dorota. 1999. "Niespełnione macierzyństwo: psychologiczna sytuacja matek po poronieniu". In: Oblicza macierzyństwa, edited by Dorota Kornas-Biela, 179-200. Lublin: Redakcja Wydawnictw KUL.

Kornas-Biela, Dorota. 2002. Wokót początku życia ludzkiego. Warszawa: Instytut Wydawniczy "Pax".

Kornas-Biela, Dorota. 2009. Pedagogika prenatalna: nowy obszar nauk o wychowaniu. Lublin: Wydawnictwo KUL.

Kryszkowski, Waldemar, Agata Karowicz-Bilińska, Antoni Florkowski and Piotr Gałecki. 2012. "Psychiczne następstwa przedwczesnego zakończenia ciąż". Neuropsychiatria. Przegląd kliniczny 4(2): 98-102.

Landwójtowicz, Paweł. 2019. "Praca z traumą relacyjną w terapii par". In: Zdrowa i mocna rodzina fundamentem społeczeństwa, edited by Józef Stala, 161-177. Kraków: Wydawnictwo Naukowe UPJPII. doi.org/10.15633/9788374387613.1

Lepiarz, Anna. 2010. "Zmiany psychiczne doświadczane przez kobiety oczekujące narodzin dziecka”. Ginekologia Praktyczna 18(1): 54-57. 
Lewicka, Magdalena, Magadelna Sulima, Maria Pyć and Barbara Stawarz. 2013. "Charakterystyka poronień i prawa przysługujące kobiecie po stracie ciąży”. Annales Academiae Medicae Stetinensis 59(1): 123-129.

Lohner, Alexander. 2002. "Historyczne korzenie etycznych poglądów Petera Singera". In: Utylitaryzm w bioetyce: jego założenia i skutki na przykładzie pogladów Petera Singera, edited by Wojciech Bołoz and Gerhard Höver, 48-99. Warszawa: Wydawnictwo UKSW.

Łuczak-Wawrzyniak, Jadwiga. 2012. "Psychospołeczne aspekty ciąży". In: Położnictwo, vol. 1. Fizjologia ciązy, edited by Grzegorz H. Bręborowicz and Wiesław Markwitz, 221-230. Warszawa: Wydawnictwo Lekarskie PZWL.

Łuczak-Wawrzyniak, Jadwiga, Marta Czarnecka and Anna Bukowska. 2012. "Strata dziecka - różne perspektywy postrzegania tego doświadczenia". In: Przegrane narodziny: strata ciązy w aspekcie psychologicznym, socjologicznym, medycznym i etycznym, edited by Ewa Dmoch-Gajzlerska and Izabela Barton-Smoczyńska, 43-53. Warszawa: Oficyna Wydawnicza Warszawskiego Uniwersytetu Medycznego.

Łuczak-Wawrzyniak, Jadwiga, Marta Czarnecka-Iwańczuk, Anna Bukowska and Nina Konofalska. 2010. "Wczesne i późne psychologiczne skutki utraty ciąży". Ginekologia Polska 81: 374-377.

Mach, Aleksandra, Agnieszka Nowacka and Ewa Dmoch-Gajzlerska. 2014. "Rola i zadania położnej w opiece nad ciężarną zagrożoną poronienie". Położna. Nauka i Praktyka 2(26): 32-38.

Melina, Livio. 2016. Kurs bioetyki. Ewangelia życia. Translated by Katarzyna Wójcik, Kraków: Wydawnictwo św. Stanisława BM.

Morciniec, Piotr. 2000. Etyczne aspekty transplantacyjnej terapii chorób neurozwyrodnieniowych. Studium teologicznomoralne. Opole: Wydawnictwo Świętego Krzyża.

Morciniec, Piotr. 2009. Bioetyka personalistyczna wobec zwłok ludzkich. Opole: Redakcja Wydawnictw Wydziału Teologicznego Uniwersytetu Opolskiego.

Morciniec, Piotr. 2013. "Pogrzeb nienarodzonego - między bólem straty a zobowiązaniem". In: $O d$ bólu po stracie do nadziei życia. Pogrzeb dziecka poronionego, edited by Jan Dziedzic and Piotr Guzdek, 99-115. Kraków: Wydawnictwo Naukowe UPJPII.

Mroczkowska, Dorota. 2011. “Jakość życia kobiet po poronieniu ciąży”. Życie i Płodność 5(4): 77-88.

Murlikiewicz, Magdalena and Piotr Sieroszewski. 2013. "Poziom depresji, lęku i objawów zaburzenia po strasie pourazowym w następstwie poronienia samoistnego". Perinatologia, Neonatologia i Ginekologia 6(2): 93-98.

Murphy, Timothy F. 1985. "The moral significance of spontaneous abortion". Journal of Medical Ethics 11(2):79-83. doi.org/10.1136/jme.11.2.79

Murphy, Samantha and Joanne Cacciatore. 2017. "The psychological, social, and economic impact of stillbirth on families". Seminars in Fetal and Neonatal Medicine 22(3): 129-134. doi.org/10.1016/j.siny.2017.02.002

Muszala, Andrzej. 2012. "Czy embrion ludzki jest osobą ludzką? Pytanie o osobowy status embrionu". In: Badania nad embrionami ludzkimi w świetle etyki i prawa, edited by Ewa Podrez and Tomasz Stawecki, 17-39. Warszawa: Wydawnictwa Uniwersytetu Warszawskiego.

O'Leary, Joann and Cecilie Gaziano. 2011a. "Sibling grief after perinatal loss". Journal of Prenatal and Perinatal Psychology and Health 25(3): 173-193.

O'Leary, Joann and Cecilie Gaziano. 2011b. "The experience of adult siblings born after loss". New Directions in Psychotherapy and Relational Psychoanalysis 5(3): 246-272.

Panay, Nick, Ruma Dutta, Audrey Ryan and J.A. Mark Broadbent. 2006. Położnictwo i ginekologia. Translated by Michał Tomaszewski. Wrocław: Wydawnictwo Medyczne Urban \& Partner.

Pikus, Joanna. 2014. "Emocje kobiet po stracie dziecka: psychologiczne etapy żałoby". Magazyn Pielęgniarki i Położnej 2: 44:45.

Pilarz, Łukasz B. 2017. „Status ontyczny zwłok i szczątków płodowych w etyce personalistycznej”. In: Filozoficzne rozważania o naturze człowieka, edited by Beata A. Nowak and Kamil Maciąg, 59-74. Lublin: Wydawnictwo Naukowe „Tygiel”. 
Prażmowska, Barbara, Grażyna Puto, Ewa Kowal and Barbara Gierat. 2009. "Niespełnione macierzyństwo". Ginekologia Praktyczna 17(4): 53-56.

Sikora, Katarzyna. 2014. "Reakcje kobiet po stracie ciąży oraz zachowania partnerów". Ginekologia i Położnictwo 9(3): 40-55.

Steuden, Stanisława and Konrad Janowski. 2016. "Trauma - kontrowersje wokół pojęcia, diagnoza, następstwa, implikacje praktyczne”. Roczniki Psychologiczne 19(3): 549-582.

Szawarski, Zbigniew. 2005. Mądrość i sztuka leczenia. Gdańsk: Wydawnictwo Słowo/Obraz Terytoria.

Szymańska, Magdalena. 2012. "Informowanie pacjentki o niepowodzeniu położniczym - badanie lekarzy”. Życie i Płodność 6(1): 45-50.

Szymańska, Magdalena and Bogdan Chazan. 2004. "Postawy pacjentek po niektórych niepowodzeniach położniczych”. Kliniczna Perinatologia i Ginekologia 40 (1): 10-14.

Szymona-Pałkowska, Katarzyna. 2005. Psychologiczna analiza doświadczeń rodziców w sytuacji ciąży wysokiego ryzyka. Lublin: TN KUL.

Ślipko, Tadeusz. 1994. Granice życia: dylematy współczesnej bioetyki. Kraków: Wydawnictwo WAM.

Wyka, Edyta. 2010. "Trudno zobaczyć w nas cierpiących rodziców”. In: Poronienie, edited by Cyprian Klahs, 81-90. Poznań: Wydawnictwo Polskiej Prowincji Dominikanów "W drodze".

Piotr Guzdek - possesses an MA in Family Studies from the John Paul II Catholic University of Lublin and an MA in Journalism and Social Communication from the Pontifical University of John Paul II and is a PhD student at the Faculty of Theology of the University of Opole, a secretary of the board of the Polish Family Association; e-mail: piotrguzdek@interia.pl, ORCID: 0000-0002-1727-8012.

Rev. Jarosław Jęczeń - possesses a PhD in theological sciences, is a university professor, researcher at the Department of Family Sciences at the Institute of Theological Sciences of the John Paul II Catholic University of Lublin; e-mail: jaroslaw.jeczen@, kul.pl. 